\title{
The Territorial Expansion of the Colonial State: Evidence from German East Africa 1890-1909
}

\author{
JAN PIERSKALLA, ALEXANDER DE JUAN AND MAX MONTGOMERY*
}

\begin{abstract}
What explains states' sub-national territorial reach? While large parts of the state-building literature have focused on national capabilities, little is known about the determinants of the unevenness of state presence at the sub-national level. This article seeks to fill this gap by looking at early attempts at state building: it investigates the processes of state penetration in the former colony of German East Africa. Contrary to previous studies - which largely emphasized antecedent or structural factors - the current study argues that geographical patterns of state penetration have been driven by the state's strategic imperative to solidify control over territory and establish political stability. The article tests these propositions using an original, geo-referenced grid-cell dataset for the years 1890 to 1909 based on extensive historical records in German colonial yearbooks and maps.
\end{abstract}

\section{Keywords: state building; colonialism; German East-Africa; Africa}

Why do states establish a formal presence in certain locations rather than others? While classic works of comparative politics and historical sociology have touched on the connection between the spatial unevenness of the state and the temporal patterns of its extension, ${ }^{1}$ little research has systematically explored the determinants of states' sub-national territorial expansion. This article aims to fill this gap by studying patterns of state expansion in a colonial setting. Rather than analyzing the development of national capabilities, we focus on the 'sub-national expansion of the state' as it applies to the spread of state institutions of control through the national territory. ${ }^{2}$

State building involves a diverse range of functions, from early attempts to establish a rudimentary infrastructure of control and coercion (our focus here) to the penetration of society with a complex web of differentiated state institutions. The process of the 'primitive accumulation of power ${ }^{3}$ constitutes an initial and basic phase of state building that focuses on establishing state presence and control; in this phase, state elites have limited ambitions beyond territorial domination, since they are often constrained by a disjuncture between their national capabilities and the size of the territory they aim to control. ${ }^{4}$ These conditions characterize a

* Authors contributed equally. Department of Political Science, The Ohio State University (email: pierskalla.4@osu.edu); Department of Politics and Public Administration, University of Konstanz (email: alexander.de-juan@uni-konstanz.de); German Institute of Global and Area Studies (email: max. montgomery@giga-hamburg.de). We are grateful for the invaluable feedback of Marcus Kurtz, Amanda Robinson, Rick Herrmann, Alex Lee, Steven Wilkinson, Robert Woodberry, Roberto Foa, panel participants at APSA 2014 and 2015, three anonymous reviewers, and Sona Golder as the responsible editor at BJPS. This project received financial support from the Gerda-Henkel Foundation. Online appendices are available at https:// doi.org/doi:10.1017/S0007123416000648 and data replication sets are available at http://dataverse.harvard.edu/ dataverse/BJPolS.

1 Boone 2003; Herbst 2000; Mann 1984; Scott 2009; Weber 1976.

2 Mann 1984; Soifer 2006; Soifer and Hau 2008.

3 Cohen, Brown, and Organski 1981.

${ }^{4}$ Herbst 2000, 76. 
transition phase, when states have claimed authority over a specific region - including in a colonized territory - but have not (yet) instigated a more comprehensive state-building project.

We focus on this initial state-building phase to formulate a theoretical argument of sub-national expansion of the state. Departing from the previous literature on institution building, we argue that in this phase political stability and territorial control - rather than structural economic, geographical or socio-demographic factors - are the prime factors guiding a state's allocation of scarce resources throughout its territory. Therefore states prioritize areas that have previously experienced violent resistance against the state, as well as those that promise to maximize territorial coverage and minimize 'blank spots' of state absence.

We investigate these arguments with a detailed analysis of colonial state building in former German East Africa. The German Empire, a latecomer to the colonial game, only sought territorial possessions in the New Imperialism stage of colonialism. ${ }^{5}$ This period was characterized by European nations' virtually insatiable hunger for territorial acquisitions overseas, as the result of a highly nationalistic environment demanding that nations solidify their international standing both internationally and domestically. As such, Germany's colonial endeavor in Africa, like other imperial powers at the time, was motivated less by resource extraction and more by a desire for prestige and competition with other European powers, which led to a very specific scope of objectives in the colony, contrasting with other phases of European colonialism. While unique in some ways, analyzing German colonial rule in German East Africa can shed light on the rudimentary processes of state penetration in the early phases of state building.

We conduct an in-depth analysis of state-building efforts by the German colonial administration in the territories of former German East Africa (which comprises today's Tanzania, Rwanda and Burundi) to test our arguments. Information on state presence and the colony's socio-economic characteristics is culled from extensive historical records found in German colonial yearbooks and maps. We digitized and geo-referenced this information to create a detailed spatio-temporal record of German colonial state-building efforts. We supplement these quantitative data with additional qualitative evidence from primary archival sources from the colony.

First, we find consistent empirical evidence that violent challenges to colonial rule were a prime determinant of the geographic expansion of state presence. Secondly, the desire to establish comprehensive territorial control motivated colonial administrators to consistently commit scarce state resources to remote and inaccessible areas of the colony, even though there was no prior indication of economic viability. These decisions allow us to infer that factors like the potential for economic extraction or cost-driving geographical and ecological features mattered much less than is often emphasized. ${ }^{6}$

Our article makes two main contributions. First, our explanation of the sub-national expansion of the state refines and extends classic theories from the comparative politics literature to understand sub-national variation in the pattern of state expansion. Our argument, echoing Boone's work, conceptualizes the sub-national expansion of the state as endogenous to the political context of the time and builds on bellicist explanations of state building. ${ }^{7}$ We show that in the 'primitive accumulation of power' phase, bellicist threats not only provide

5 New Imperialism refers to a period of enormous colonial expansion, in particular by European powers, in the late nineteenth and early twentieth centuries. Colonial acquisitions made in this era were generally driven by both ideological reasons and a desire for state expansion, rather than resource extraction or for the purposes of settlement (Young 2001). While there are notable exceptions, such as large parts of Northern Africa and South Africa, the majority of colonial acquisitions in Africa fall into this category.

6 E.g. Acemoglu and Robinson 2012; Engermann and Sokoloff 2002.

7 Boone 2003; Tilly 1990. 
incentives to build state capacity, as prominently argued by Tilly; the geographic distribution of these threats shapes the spatial configuration of state capacity. Moreover, our analysis documents the political and incremental nature of state expansion. Political dynamics - which are often characterized by reactive, on-the-ground decision making rather than structural geographic, demographic or economic factors - appear to be the primary catalyst for the subnational expansion of state institutions. This theoretical account differs from existing work, for example, Tilly's argument of war making as state making, due to its focus on the spatial dimension of state building at the sub-national level and a more explicit treatment of actual strategic decision making by state actors.

Secondly, our findings add to research on the long-term repercussions of early phases of state building. More generally, a growing body of work has identified 'critical junctures' during periods of pre-colonial and colonial rule and emphasized the importance of early state building, in particular its type and spatial extent, for modern institutions and current levels of economic and political development. ${ }^{8}$ While this research focuses on the consequences of the historical processes of state building and state expansion, ${ }^{9}$ there has been less systematic research on the exact determinants of spatial state-building patterns during the colonial period. Our findings contribute to this research by providing evidence of the factors that drove specific instances of rudimentary state building.

\section{PRIMACY OF TERRITORIAL CONTROL IN 'PRIMITIVE' STATE BUILDING}

What explains geographic patterns of state expansion? More general work on the emergence of the modern state in Western Europe has emphasized opportunities for extraction as a main catalyst for state building and a primary determinant of its shape. ${ }^{10}$ According to this literature, the state's survival depends on its ability to extract resources from its land and population. ${ }^{11}$ Its most prominent proponent, Tilly, elaborates on the dual function of taxation: funding further state expansion while catalyzing state control by increasing administrative capacity. ${ }^{12}$ The literature on colonial state building has even more strongly emphasized extraction as the main motive shaping the decision making of European powers during this time. ${ }^{13}$

A second powerful motif evoked by the literature is that of the state restrained by its physical and financial limitations, such as geographic constraints and cost considerations. Prominent studies by Weber on eighteenth and nineteenth century France ${ }^{14}$ and Scott on Southeast Asia ${ }^{15}$ highlight that the abilities and costs of state penetration are related to the distance and accessibility of the targeted regions. Similarly, Herbst ${ }^{16}$ stresses that colonial states active in sub-Saharan Africa during this time were engaged in a minimal set of activities, which they

${ }^{8}$ E.g. Acemoglu, Johnson, and Robinson 2001; Hariri 2012; Mahoney 2010. Appendix Section 14 briefly discusses the implications of our analysis for long-term development.

${ }^{9}$ We use two common terms: 'state building' and 'state expansion' throughout the article. We use a simple and intuitive definition for the first: the process of creating new state institutions or strengthening existing ones (Fukuyama 2004). We use 'sub-national expansion of the state' in a similar sense, but with a more geographical connotation, namely for the process of creating state institutions in geographical areas where the state has previously not been present.

${ }^{10}$ Levi 1989; Organski and Kugler 1980; Seidman 1986; Tilly 1990.

11 Levi 1989; Tilly 1990.

12 See also Finer 1975.

13 Acemoglu, Johnson, and Robinson 2001; Engerman and Sokoloff 2002; Huillery 2011; Lange, Mahoney, and vom Hau 2006; Naritomi, Soares, and Assunção 2012.

14 Weber 1976.

15 Scott 2009.

16 Herbst 2000. 
tried to carry out at the lowest possible cost. In remote areas with low population density, the costs of controlling large territories often exceeded the marginal revenues of trade and taxation. Consequently, state expansion was less likely in areas that were difficult to reach from the state's power base. This suggests a model of developing colonial state institutions in concentric circles around administrative capitals.

A third prominent explanation of state building stresses the role of war and violence. Tilly conceptualizes the elimination of internal rivals as a key dynamic of state formation in Western Europe. ${ }^{17}$ This process of 'state making' led to the monopolization of power and created incentives for extraction. ${ }^{18}$ Migdal theorized state penetration as a conflict over social order and control. As the state is just one of many actors claiming authority over territory and people, its penetration of society depends on its ability to prevail over competing social organizations. ${ }^{19}$ While qualitative analyses highlight repression and resistance as key features of the colonial state-building process, ${ }^{20}$ spatial configurations of the state have not been systematically traced back to dynamic patterns of violent opposition. Moreover, existing accounts have not discussed how informational constraints shape the strategic decision making of state actors in early phases of state building.

We believe that all three perspectives highlight essential elements of complex long-term state-building processes. We add to this work by narrowing our analytical focus to a specific phase of state building: an early and transitional phase in which states face the challenge of establishing authority over newly claimed territories with very limited resources at their disposal. These situations regularly display three main characteristics.

First, they constitute 'initial' phases of state building. While the targeted region may have been brought under de jure state authority, an infrastructure of control and coercion has yet to replace the pre-existing social and political order. Secondly, the state-building project has limited ambitions. The "hegemony imperative" ${ }^{21}$ is the primary driving force, either to prepare the ground for more far-reaching state activities or because the territorial occupation had limited objectives in the first place - to establish tributary relations, bolster a country's prestige or create a military/political buffer zone. Finally, this phase of state building is marked by a mismatch between the state's overall capabilities and the size of the territory. Effectively controlling large regions requires substantial financial and human resources that are rarely available in the initial phases of state building, which forces states to make strategic decisions about the spatial allocation of their resources. This produces state-building efforts that are characterized by weak state capacity, a lack of resources and a lack of information about local conditions within a multi-ethnic setting of competing social organizations.

When (and where) does this type of state building take place? Most states have not emerged full-blown, but after an intermittent process of expansion and consolidation of state authority. ${ }^{22}$ Substantive territorial conquests during expansion phases create the conditions sketched above: states need to erect an infrastructure of control. Pre-existing social and political organizations challenge their authority and require the new hegemon to prioritize the monopolization of

17 Tilly (1990) further asserts the importance of 'war making' in the process of state building in Western Europe, essentially referring to the elimination of external threats from outside powers. However, as European powers had divided African territories among themselves and carved out their borders at the Berlin Conference, this argument is not applicable to this context.

18 Tilly 1990.

19 Migdal 1988.

${ }^{20}$ Boone 2003; Herbst 2000; Young 1994.

21 Young 1994, 10.

22 Levi 1989. 
violence. States have to incur the associated costs before they can capitalize on access to the resources of the newly conquered territory. Several state-building processes around the world have taken place under such conditions. For example, the massive expansion of the small Gorkha kingdom in the 18th and 19th century to more than the size of present-day Nepal, ${ }^{23}$ or the conquest of territories many times the size of its original center of power by the pre-colonial kingdom of Burundi in the 17 th and 18 th centuries, ${ }^{24}$ or when the Ethiopian state expanded southwards in the second half of the 19th century to establish the 'Naftagna' ('one with gun') system in newly conquered restive regions to establish order and authority ${ }^{25}$ are all cases of early phases of state building. More commonly treated in the literature, Western Europe is similarly characterized by periods of internal conquest and state penetration that preceded the inception of modern states. ${ }^{26}$

Challenges of post-civil war state building are equally affected by the three conditions outlined above. Many civil wars last for several decades, with rebel groups effectively controlling large portions of a country and displacing state institutions. Peru and Colombia, for example, experienced more than ten years of rebellion by strong insurgent groups that established state-like structures in the hinterlands of their territories. ${ }^{27}$ When such protracted conflicts end, states need to virtually 'restart' the state-building process in the former strongholds of armed groups. While their objectives certainly go far beyond pure effective occupation, states need to focus on pacification first in order to prevent any relapse into disorder. Weakened by enduring violent conflict, states face the challenge of trying to 'reconstruct' former restive regions with very limited financial and human resources.

Finally, colonial powers engaged in this type of state building during the New Imperialism period, particularly in sub-Saharan Africa. In most colonies, actual penetration of the territory was extremely limited before the Berlin Conference, when metropolitan states demarcated and claimed vast territories in the course of only a few years. ${ }^{28}$ Until the beginning of WWI, many colonial states were preoccupied with establishing a basic coercive apparatus and trying to fulfill the obligation of 'effective occupation' emanating from the Berlin Conference ${ }^{29}$ and preparing the ground for the effective extraction of natural resources. Virtually all colonial administrations had to embark on this task with very limited resources. ${ }^{30}$ While the processes of state building differed across colonial powers, these differences were more in magnitude than in the nature of the challenges they faced and the resulting framework for state penetration.

Thus, while we believe our arguments apply to a broader set of state-building cases, we focus on early colonial state building following the 'scramble for Africa'. The following subsections introduce our theoretical argument. We first lend support to our basic assumption that this phase of colonial state building was driven by the 'hegemony imperative'. ${ }^{31}$ The subsequent sections elaborate on our two main hypotheses.

23 Whelpton 2005.

${ }^{24}$ Mworoha 1987.

25 Tibebu 1995.

26 Tilly 1990; Weber 1976

27 Wickham-Crowley 1993

${ }^{28}$ Herbst 2000.

${ }^{29}$ In 1885, colonial powers agreed at the Berlin Conference that they had 'the obligation to ensure the establishment of authority in the regions occupied by them' (General Act of the Berlin Conference, Chapter 6, Article 35).

${ }^{30}$ Herbst 2000; Killingray 1999; Young 1994.

31 Young 1994, 10. 


\section{Defending the State}

Extraction and cost considerations were most certainly important to any state-led colonial project. Yet we believe it is necessary to expand this narrow focus in the existing literature by emphasizing the political dynamics of colonial rule. We argue that an image of colonial government that is concerned with projecting power is more fitting than that of a onedimensional extractive, cost-sensitive state. In contrast with private colonial actors (for example, traders or missionaries), state agents prioritized territorial control and order over extraction. These imperatives were particularly dominant during the late nineteenth century, when European powers were in heightened competition with each other, trying to satiate their hunger for the expansion of their empires. This perspective returns the primary focus to the bellicist dimension of the classic predatory model of state building ${ }^{32}$ and shifts the emphasis to subnational variation in state presence. ${ }^{33}$ Similar to Boone, our explanation explicitly understands the evolution of state building as an endogenous process that is sensitive to the political context of the time, but highlights learning processes and the dynamic nature of political bargains that underpin the expansion of colonial power. ${ }^{34}$ Thus we essentially understand (colonial) state building as a process of demarcating distinct spheres of influence and establishing a physical presence in claimed territory. ${ }^{35} \mathrm{We}$ argue that there are three main reasons for this.

First, due to its own weakness, the colonial state was under high internal pressure to maintain order and control. Its claims of authority inevitably clashed with competing social organizations and their respective entrepreneurs who aimed to shield their authority from the state. ${ }^{36}$ The weaker a state, however, the more its stability depends on its ability to constantly demonstrate its resolve and capacity to swiftly and brutally quell any form of resistance. 'Bloody proofs' of superiority are even more essential for deterring opposition where the state has to control vast areas with very limited resources in terms of personnel and infrastructure. From the colonial agents' perspective, acts of opposition can create violent spillover effects by revealing the state's weakness and thereby motivating further rebellion, thus threatening the entire statebuilding project. ${ }^{37}$ Thus while traders, missionaries and planters may have concentrated on calmer regions with high extractive potential, colonial states were under high internal pressure to design their expansion in a way that allowed them to prevent or suppress any defiance of their authority. ${ }^{38}$

Secondly, in 1885, colonial powers agreed at the Berlin Conference that all colonial powers had 'the obligation to ensure the establishment of authority in the regions occupied by them'. 39 In parallel, the international codification of colonial borders lessened the need to secure borders and allowed rudimentary colonial state governments to focus on internal challengers. Furthermore, in an increasingly aggressive nationalist environment, trouble within the colonies could easily damage a colonial power's imperialist prestige. The inability to control colonial subjects, in particular the inability to prevent violent uprisings, was interpreted as a sign of weakness and damaged the metropolis' reputation both domestically and internationally.

32 E.g. Thies 2007; Tilly 1990.

33 While Thies (2007) does consider the importance of internal rivals for increasing state capacity, his analysis is constrained by aggregate country-level data and his choice of dependent variable. Measuring state capacity using the tax-to-GDP ratio conflates extractive motives with issues of territorial control.

34 Boone 2003.

35 Kabwegyere 1972

36 Herbst 2000.

37 Henley 2004; Trotha 1994.

38 Huillery 2011.

39 General Act of the Berlin Conference, Chapter 6, Article 35. 
This added another layer of pressure for colonial administrators to create a state apparatus that maximized territorial control and security.

Finally, ensuring territorial control and security constituted an essential prerequisite for all other types of state activities, such as extraction. In most colonies, the main revenues stemmed from tax extraction and agricultural activities that relied heavily on forced labor. ${ }^{40}$ In other words, most extractive activities depended on people. ${ }^{41}$ Resistance jeopardized the extraction of these resources, wherever it occurred, by absorbing scarce capital and manpower from colonial economic projects, such as trade, agriculture or public works; driving away foreign private investment; and preventing access to areas with high levels of opposition. ${ }^{42}$ Consequently, territorial control and order not only constituted priorities in themselves but were also crucial prerequisites for all other administrative and economic objectives of the colonial state and its metropolis.

\section{Hypothesis 1: Maximizing Territorial Coverage}

The primary concern about territorial control suggests that geographic distances played an important role in shaping colonial decisions about costly investments in state presence and capacity. Herbst argues that remoteness is a detriment to state presence due to the higher costs of state penetration. ${ }^{43} \mathrm{We}$ instead argue that high costs should not prevent state expansion when there exists a strategic motive to expand, for example when the expected benefits or the costs of inaction surpass the immediate burden of the investments. ${ }^{44}$ Consequently, costs will often be a second-order concern in 'primitive state building' where the state's primary objectives are to maximize territorial control and consolidate its authority. States have to invest military and administrative resources in remote and difficult-to-reach areas in order to signal their resolve and safeguard their entire colonial endeavor. This investment is a matter of survival, and cannot be compromised due to mere financial reasons. ${ }^{45}$

From such a perspective, colonial powers should not avoid investing in strengthening the state's presence in far-away areas. On the contrary: they should aim to close existing gaps in their territorial coverage. The 'doctrine of effective occupation' requires states to establish a 'skeletal grid of regional administration' that encompasses all of their territories. ${ }^{46}$ As Machiavelli recommended to the prince in reference to the stabilization of colonies, presence is an essential symbol of power and helps identify potential areas of resistance. Echoing this recommendation, the French military, during its mandate rule in Syria, stressed the need to establish a presence in difficult-to-reach areas 'to demonstrate to the population that at any time we are capable of rapidly bringing a sizable force to the Mountain and by its presence at the heart of the country to warn against any attempt of uprising ${ }^{47}$ Similarly, Killingray emphasizes that in Nigeria, colonial "military headquarters stood in strategic centers at the heart of newly conquered territories' to signal authority and deter any potential rebellion. ${ }^{48}$

40 E.g., Banerjee and Iyer 2005.

41 Acemoglu, Johnson, and Robinson 2001; Young 1994.

42 Huillery 2011.

43 Herbst 2000.

44 E.g., Lange, Mahoney, and vom Hau 2006.

45 Young 1994, 35.

46 Young 1994, 100.

47 Neep 2012, 104-5.

48 Kilingray 1986. 
Consequently, rather than expand state capacity in areas that are easy and cheap to access, we expect new frontier outposts to be placed in order to maximize the state's reach and minimize the distance from any location in the territory to the nearest administrative and military center. Such a strategy of state penetration serves the 'hegemony imperative' of primitive state building: it increases the share of the local population exposed to symbols of state authority and reduces the time needed to deploy troops to any location in the territory. Thus the build-up of state capacity should be most likely in locations with high 'territorial control values' ${ }^{49}$ in the centers of thus-far-uncontrolled regions, where the establishment of a state presence promises to maximize additional territorial coverage.

Hypothesis 1: The higher an area's territorial control value, the higher the probability of state penetration.

\section{Hypothesis 2: Reacting to Violence}

A second corollary to the primary concern about territorial order and control is that early state builders tended to react to actual instances of violent opposition rather than theoretical assessments of structural preconditions. It has been argued that in the pursuit of their objectives (that is, taxation), states are constrained by certain features of the societies they govern, which means that state administration will likely be designed to be most efficient given the prevailing structural conditions. ${ }^{50}$ This perspective has also been applied to explanations of the unevenness of colonial states. It has been argued, for example, that the type and intensity of colonial rule were heavily influenced by levels of pre-colonial ethnic organization and centralization. ${ }^{51}$

While such structural conditions are likely to shape state building, we want to emphasize that state building generally takes place under conditions of uncertainty and a lack of accurate information - particularly in the very early stages. It is difficult for administrators to gather information about the societies they claim control over. ${ }^{52}$ This struggle for information has been an especially important feature of colonial rule. ${ }^{53}$ Thus knowledge was generally insufficient to develop a meaningful and sound strategic approach to the specific local context. ${ }^{54}$ While colonial agents may have tried to incorporate basic information about existing tribal and political structures into their planning, their information was often incorrect. ${ }^{55}$ Similarly, indigenous populations that entered preliminary bargains with colonial powers were not immune to errors of judgment and miscalculations. Initial bargains, meant to instantiate indirect rule, often fell apart when local leaders saw an opportunity to challenge the colonial powers, often underestimating the intensity of the response. Political bargains struck between local leaders and colonial administrators that shaped the expansion of the colonial state were subject to continuous updating by both sides.

We believe that this context of uncertainty led to the prioritization of actual experiences over theoretical knowledge. Consequently, the state's path of encroachment was shaped mainly by trial and error; strategies were adjusted after new first-hand information became available. Since colonial powers were very concerned with maintaining their reputations and were easily

${ }^{49}$ We provide an operationalization and illustration of this variable in the empirical section.

${ }^{50}$ E.g., Levi 1989.

51 Acemoglu, Johnson, and Robinson 2001; Boone 2003; Gerring et al. 2011; Mamdani 2011.

${ }^{52}$ Evans, Rueschemeyer, and Skocpol 1985.

53 Steinmetz 2008.

${ }^{54}$ Callahan 2002.

55 Banerjee and Iyer 2005; Le Meur 2006; Steinmetz 2008; Wilson 2011. 
threatened by resistance in any form, violence must be considered the most important type of new information in this context. ${ }^{56}$ Thus we hypothesize that state expansion was driven by responses to acts of violent resistance, rather than by specific structural features such as the internal organization of ethnic groups. This implies that colonial state penetration is a function of resistance by the local population.

Hypothesis 2: The higher the level of previous violence, the higher the probability of state penetration.

This hypothesis represents a useful refinement of classic bellicist accounts of state building. In essence, we are arguing that the sub-national distribution of manifest threats to state rule shaped the state's presence and capacity at the sub-national level. Before we present the data we use to operationalize and measure the variables, we briefly introduce our historical case, focusing on the period of analysis: 1890-1909.

\section{COLONIAL STATE BUILDING IN GERMAN EAST AFRICA}

Early German colonization efforts in Africa were initially carried out by a number of private explorers motivated by personal gain and commercial ambitions. In 1884, Carl Peters founded the Society for German Colonization, which lobbied for the acquisition of colonies and soon evolved into the German East-Africa Company (Deutsch Ostafrikanische Gesellschaft, DOAG). In order to exert pressure on the reluctant Bismarck, and to fulfill his desire for profit and fame, Peters undertook a series of expeditions throughout East Africa, during which he signed obscure treaties with what he assumed to be local authorities, which transferred their land to the company 'for all times' ${ }^{57}$ In the beginning of 1885 , Bismarck caved in to Peters (who was threatening to seek support from Leopold II of Belgium instead) and to an increasingly imperialistic public, and officially legitimized DOAG's territorial possessions in Africa.

During the following years, the borders of German East Africa were defined through interactions with neighboring European colonial powers and DOAG, invigorated by the imperial government's support. DOAG continuously expanded its territorial presence by establishing a number of small trading stations in coastal areas. ${ }^{58}$ The company increasingly intervened in pre-existing cultural, political and economic structures, predominantly by establishing authority over tariffs and taxes, jurisdiction and land rights. ${ }^{59}$ In 1888 , in response to DOAG's heavy interference in political and economic affairs along the coast, local wealthy merchants and landowners began to mobilize resistance against the German intruders in the so-called Abushiri Revolt. ${ }^{60}$ Bismarck initially hesitated to intervene on behalf of DOAG, but finally decided to charge Hermann von Wissmann with commanding a hastily recruited contingent of local soldiers to quell the resistance. By 1890, the military campaign had crushed the revolt and executed its eponymous leader. ${ }^{61}$ Afterwards, the German government integrated

56 Berman 1998; Boone 2003; Shenton 1986.

57 Bückendorf 1997; Klein-Arendt 2005.

58 Bückendorf 1997; Iliffe 1979.

59 Bückendorf 1997. In most of the hinterland, however, the company had little impact on the local population (Pesek 2005).

${ }^{60}$ German contemporary sources mistakenly label the incident as the Arab Revolt. Contrary to the German perception, the revolt was not an Arab affair, but united a number of peoples in the territory against DOAG (Pesek 200).

61 Bückendorf 1997; Iliffe 1979. 
the East African territories into the empire and established full-scale colonial rule by assuming all administrative functions and appointing von Wissmann's troops as a colonial force. ${ }^{62}$

In the early years of German imperial rule, colonial state building was characterized by substantial internal contradictions. ${ }^{63}$ The colonial regime's military superiority allowed it to strengthen its grip over the entire territory despite encountering bitter resistance. Yet there was no blueprint for establishing territorial domination, and the central administration, which was very understaffed and underfunded, was almost unable to effectively govern the territory. Thus military control and civil bureaucracy were spread thinly across the territory, and were mainly confined to local hubs of state presence. ${ }^{64}$ In 1905, the total German colonial administrative and military staff numbered a meager 403 for an area of approximately 200,000 square kilometers.

In an attempt to control as much area as possible with the limited resources available, the colonial state was constructed through the consecutive establishment of administrative and military posts, each headed by military officers or civilian station chiefs. ${ }^{65}$ German stations were in charge of carrying out all of the rudimentary functions of the colonial state: assuring order and stability, collecting taxes, and promoting the production and trade of agricultural products in which the Germans were interested. ${ }^{66}$

Given the limited availability of manpower and resources, establishing direct rule over the territory was deemed impossible. Hence, various modes of direct and indirect rule were established - depending on the reaction of the local population to German claims of authority, as well as local political and social conditions (as interpreted by the Germans) - in which native elites came to play a significant role as intermediaries in colonial administration. ${ }^{67}$ In return for their obedience, the German administration granted a certain degree of self-governance to ostensibly influential leaders. ${ }^{68}$

Violent resistance and repression were endemic to the colonial subjugation project, but reached an unprecedented level with the beginning of the so-called Maji Maji rebellion in 1905. The revolt was the greatest uprising against colonial rule in early colonial East and Central Africa. It was violently crushed by German military repression in $1907 .{ }^{69}$ In the rebellion's aftermath, the new German governor, Albrecht von Rechenberg, envisioned a more economic approach to colonization, which was encapsulated in his notion of 'colonial development' ${ }^{70}$ By developing East Africa's infrastructural services, the central administration hoped to unleash its economic potential and turn it into a trading colony. ${ }^{71}$ To summarize, the case of German East Africa provides an excellent opportunity to study the early colonial state-building process of an imperial nation in the New Imperialist period. Although it contains unique features, it is generally comparable to the activities of other imperial nations at the time, particularly in sub-Saharan Africa. This is predominantly due to the strong emphasis on establishing internal control and relatively limited economic extraction. However, it is interesting to note that, following the early consolidation period, extractive ambitions began to play a more fundamental role in the strategic planning of the colonial administration. Yet this occurred right before the

62 Iliffe 1979; Pesek 2005.

63 Koponen 1995.

64 Koponen 1995; Pesek 2005.

65 Gwassa 1973.

66 Iliffe 1979; Koponen 1995.

67 Iliffe 1979; Koponen 1995.

68 Cameron 1937; Hartleb 1941; Liebenow 1971.

69 Becker 2004; Koponen 1995.

70 Koponen 1995, 241.

71 Iliffe 1979; Koponen 1995. 
end of German colonial rule following Germany's defeat in WWI, thereby barring us from investigating the consequences of these deliberations any further.

\section{DATA AND MEASUREMENT}

To determine which factors explain the patterns of German colonial state expansion, we now turn to a statistical analysis. The first step is to identify a useful unit of analysis. Districts were the only meaningful and formalized administrative units of the German colonial state. Yet these covered fairly large, heterogeneous geographic areas and were altered several times. Due to the absence of smaller, second-tier units that would allow statistical analyses on a more disaggregated level, we created an artificial grid net of $45050 \times 50$ kilometer-sized cells covering the territory of the colony. The cells were sized in order to generate a sufficient number of cases for meaningful statistical analysis, while considering potential imprecisions resulting from the geo-referencing and geo-coding of the colonial maps. The horizontal and vertical outer boundaries of the grid net have been defined randomly. All outcome, explanatory and control variables presented below are measured per grid cell. They all stem from the following original source materials (additional information on the sources is available in the Appendix).

The German Imperial Colonial Office produced annual reports from 1892 to 1914 on the colonies with substantive statistical annexes. They provide extremely rich information on various social, economic and political issues. We have assigned relevant information to specific geographic locations using a geo-coded reference map produced with high-resolution scans of the 1920 German Colonial Atlas as well as a complete village and location register that accompanies the atlas.

The second source is a number of thematic maps produced by the colonial government and various other institutions (such as colonial or missionary societies). The maps display, among other things, the location of military and missionary stations as well as the placement of various plantations and roads. We have scanned and geo-referenced these maps and extracted relevant information using GIS software (QGIS 2.0.1).

The third source is individual records by colonial agents - namely, a book from 1911 by Nigmann, a former major in the German colonial force. His account of the German military in the colony contains detailed information on the establishment of German stations and violent military encounters. ${ }^{72}$

Taken together, these data provide a unique insight into the spatial features of the German colonial state and allow for an investigation of the spatio-temporal patterns of state expansion. We would like to emphasize that colonial data should be used with caution. Working with historical data sources carries the risk of substantial measurement bias and missing information. Likely, several of our measures are affected by some amount of underreporting, misreporting and inaccuracy. We tried our best to limit this risk by relying on source material and variable operationalizations that leave little room for systematic manipulation or measurement error. Most of our primary variables are based on distances that we calculated ourselves, which rely on geo-coded information on village names - for example, distances to German stations or the location of violent clashes. We have no reason to believe that information on location names was systematically biased in German statistical reports. It is hard to think of plausible reasons why German colonial staff would manipulate other information we use, such as data on roads and caravan routes or the location of plantations.

72 Nigmann 1911. 
Moreover, we have good reason to believe that the colonial maps provide comparably accurate geographical representations. It has been reported that German colonial agents, as well as members of numerous expeditions through the colony, were eagerly trying to provide maps of the colony that were as detailed and accurate as possible. ${ }^{73}$ Maps played an essential role in all kinds of military expeditions, political planning and economic activities. It is thus not surprising that the colonial government invested heavily in producing accurate maps of its colonial territory. To account for any remaining inaccuracies of these maps, or from the process of geo-referencing, we rely on a dataset with a comparably crude scale, namely $50 \times 50$ kilometer grid cells. Finally, since our goal is to understand the motives behind state expansion from the colonial government's perspective, it is to some extent an advantage to rely on source material that reflects the information that was available at the time. Even if our data are not accurate in the objective sense, as long as this information guided and shaped colonial administrators' decisions, we are able to estimate our quantities of interest.

\section{The Outcome Variable}

Penetrating the colony's vast territory was among the main challenges of the colonial state. The German administration claimed most parts of the territory early on. However, brief expeditions into the hinterland did not permit any effective defense of these claims. This was only possible through the establishment of a continuous presence in the respective areas. The role of the stations in state penetration cannot be overemphasized. As Trotha argues with respect to German colonialism in Togo, 'The state begins with the station. ${ }^{74}$ Authority was gradually expanded from the stations, where all activities related to state functions were performed. ${ }^{75}$ Stations were responsible for securing trade along the caravan routes, taxing the local population, administering forced labor and ensuring jurisdiction. ${ }^{76}$ Consequently, the spatiotemporal advancement of state expansion can be traced through the establishment of German stations. ${ }^{77}$ Hence, our first indicator measures the presence of a German station. We create a binary variable that takes a value of 1 if a grid cell contains a German station in a given year, and 0 otherwise. Figure 1 depicts the location of German stations at the outset of colonial rule (1890) and at the end of our study period (1909).

We also measure the qualitative investment of state resources in each grid cell. To that end, we exploit the type of stations as an additional, ordinal indicator of the degree of state penetration: grid cells are assigned 'status' codes depending on the type of station they contain ranging from no station to low-level military posts to full civilian stations.

\section{The Explanatory Variables}

Our empirical analysis focuses on two main explanatory variables: the territorial control value and resistance by the local population. The following section describes our operationalization of these variables based on the sources introduced above. While we emphasize the dynamic and strategic character of state building, we are aware that processes of state expansion

${ }^{73}$ Hafeneder 2008.

${ }^{74}$ Trotha 1994, 58 'Der Staat beginnt mit der Station' in the original (authors' translation).

${ }^{75}$ Koponen 1995.

${ }^{76}$ Pesek 2005.

${ }^{77}$ Koponen 1995. 


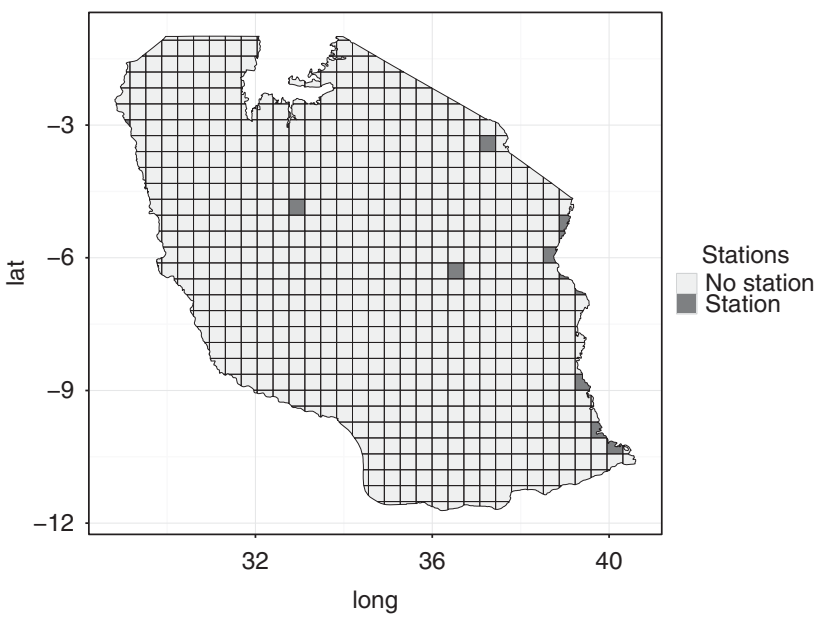

Fig. 1a. Station presence in 1890

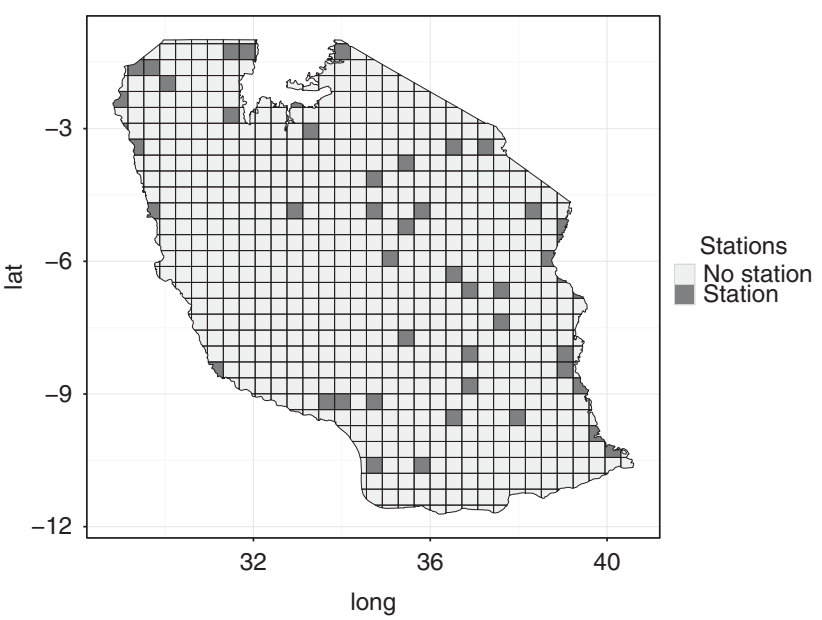

Fig. 1b. Station presence in 1909

(and adaptations to changing political or economic conditions) take time. All indicators presented below are therefore measured with a one-, two- and five-year time lag.

As argued above, the spatial expansion of the state evolved gradually over time in German East Africa. Each new station increased coverage of the remaining territory, not only by reducing the number of regions without a colonial presence, but also by reducing the distances from the remaining areas without a colonial presence to their nearest German stations. If state expansion was motivated by the objective of increasing spatial coverage of the territory, the colonial administration should have prioritized new stations in areas that promised a maximum of additional coverage.

To capture the Territorial Control Value of a location, we determine for each grid cell without a station how valuable this location is with respect to the political goal of consolidating the colony's overall territorial control. Specifically, we calculate the minimum distance from 
each grid cell $i$ to the nearest colonial station in grid cell $j$ in year $t$. We then consider how these minimum distances would change if a new station were to be built in grid cell $i$. The variable Territorial Control Value is then simply the expected overall decrease in minimum distances from each grid cell to its nearest station if a station existed in that grid cell. Figure 1 in Appendix Section 1.10 provides a visualization of the construction of our measure. By definition, the territorial control value is positive, and higher values indicate a potential increase in geographic coverage. For grid cells that already have a station, we assign the strategic value before the station was created - otherwise, grid-cell years with stations would receive a zero strategic value for all years past the initial year with a station, creating an artificial negative correlation between station presence and strategic value. ${ }^{78} \mathrm{We}$ then standardize this variable.

For our second explanatory variable, we are using information provided by Nigmann. His book contains a detailed account of all major battles fought by the German colonial forces between 1889 and 1910. Out of a total of 235 entries, 200 contain explicit information on the location of the battle. We were able to geo-locate 166 of these events. ${ }^{79} \mathrm{We}$ create two separate variables to capture the level of resistance within a given grid-cell area. First we create a simple yearly count variable for all battles that took place within the grid cell. Considering that the location of a major battle indicates a certain level of resistance in the surrounding areas, we also measure each grid cell's distance to the nearest major battle. We then standardize both variables and calculate a simple average. This Battle Index represents a summary measure of the level of local resistance to German rule. ${ }^{80}$ Note that there is a concern of reverse causality between our Battle Index and the presence of a German station. If the local population expected the creation of a German station, they might have engaged in violent resistance to pre-empt its establishment. Hence, lagging this variable by several years is particularly important. Despite lagging the variable, we consider the Battle Index to be partially endogenous, but include it in the model to establish descriptive patterns. ${ }^{81}$ We then explore the issue of causality in more detail in our robustness checks.

\section{Control Variables}

We control for a number of possible confounding variables. Note that many of our control variables are time invariant and only provide cross-sectional information. We control for two features of local ethnic groups in our models: ethnic group size and integration into the German military. We use information from the Military Orientation Book for German East-Africa (Militärisches Orientierungsheft für Deutsch-Ostafrika), which was prepared by the German military and published in 1911. According to the introductory remarks by Kurt Freiherr von Schleinitz, commander of the German colonial forces from 1907-14, the book aims to provide 'a picture of the colony as needed by soldiers in German East Africa'. It includes information on

78 For the initial set of stations that existed in 1890, the territorial control value is not well defined. Instead of assigning missing values, we assign the average strategic value of all grid-cell years in the sample, assuming that initial stations were created in areas that provided some form of territorial coverage. Note that assigning the average value biases this measure against our hypothesis, since these initial grid cells were likely to have been of higher strategic value than 'the average'.

79 Note that this leaves a meaningful amount of battles outside of the analysis. The concern is that, e.g., missing events are particularly common in regions that are characterized by a lack of colonial state presence. While we were unable to geo-reference sixty-nine events, Nigmann's book does contain some information on these encounters. We were unable to discern meaningful patterns in terms of timing, larger geographic region or combatants that correlate with the absence of specific geographic information.

${ }^{80}$ We repeat all our analyses using the two constituent variables without changing any of our findings.

81 Excluding this variable from the model does not affect the results with respect to our measure of the territorial control value in any way. 
the size of ethnic groups, which we used to identify rough ethnic settlement patterns. For each grid cell we identified which ethnic settlement area its centroid is located in. We then assigned the group's population size to the respective grid cell. Considering that population size varies greatly between 1,000 and over one million, we use a log-transformed population count. Using information from an early German statistical report, we also constructed a variable for the degree of ethnic group integration into the colonial state. We assigned the number of troops in the colonial forces stemming from the respective local ethnic groups. Both indicators are time invariant.

Next we include a number of geographic features that may have influenced spatio-temporal patterns of state expansion: elevation, precipitation, the disease environment and temperature. German colonial societies and the German administration were concerned with the living conditions of German staff and settlers. A number of studies were undertaken to identify more or less hospitable areas of the colonial territory. Such considerations may have also driven the spatio-temporal expansion of the colonial state. We calculated the mean elevation per grid using the Shuttle Radar Topography Mission $1 \mathrm{~km}$ resolution data. To measure precipitation and average temperature, we use geo-referenced information from the WorldClim project (1950-2000), validated by historical sources (see the Appendix for details). Detailed maps on the presence of the tsetse fly allow us to determine for each grid cell the local disease burden, measured as a simple count of locations within a grid cell with tsetse fly populations. Again, each of these indicators only provides cross-sectional variation.

To measure the potential for economic extraction, we consider agricultural production in the colony. Four agricultural products played essential roles in German East Africa: coffee, cotton, sisal and rubber. We focus on two of these products, rubber and cotton, as their production experienced the highest increases during the period under investigation - mainly, but not exclusively, because of the tremendous increase in German demand for these products. ${ }^{82}$ To measure the local extractive potential for rubber and cotton production, we construct a measure of soil suitability for each product. Landolphia kirkii, the rubber species found most commonly in the former German East Africa, grows best in hot and humid areas with low elevation and sandy soils. ${ }^{83}$ We created a simple averaged index using elevation data from the Shuttle Radar Topography Mission (elevation below 500 meters), information on climatic conditions from a study on rainfall and temperature in German East Africa ${ }^{84}$ ('very hot and humid' regions) ${ }^{85}$ and data on soil properties from the European Soil Portal for Africa (minimum 50 per cent sand in soil). By contrast, cotton is a much more flexible plant. Hence, we rely on a general indicator of soil suitability for agriculture from the Harmonized World Soil Database. ${ }^{86}$ We also added data on the yearly world market price of cotton and rubber. ${ }^{87}$ The extractive potential of each product is modeled via the soil quality measures, world market prices and their respective interaction terms. World prices and interaction terms vary over time.

${ }^{82}$ Koponen 1995.

${ }^{83}$ Ehrhardt 1903; Schnee 1920; Sethuraj and Mathew 1992.

${ }^{84}$ Marner 1940.

${ }^{85}$ German statistical yearbooks contain information on precipitation and temperature for a number of weather stations. Unfortunately, reliable extrapolation of information across all parts of the colony is not viable, as too few such stations existed. We compared climate information from a total of forty-one stations across the colony with current climate information from the WorldClim project (1950-2000) for the exact same locations. Precipitation correlates at 0.85 and temperature at 0.9 . While correlation is not perfect, we believe that using highly disaggregated current data provides a more accurate representation of spatial climate variations than extrapolations of historical data. We aggregated WorldClim data per grid cell.

${ }^{86}$ Fischer et al. 2008.

${ }^{87}$ Blattman et al. 2007. 
We also use geo-referenced colonial estimates of overall population density to construct an ordinal, time-invariant indicator of population density for each grid cell. Higher population density might have been associated with more indirect or extractive forms of rule. ${ }^{88}$

Finally, we consider additional logistical factors. Herbst has highlighted the role of transportation infrastructure and road density as an indicator of the colonial ability to project power. ${ }^{89}$ It may also be argued that state expansion was driven by the objective of securing the territory against surrounding colonial powers. According to such a perspective, we expect state presence to be particularly strong near international borders. Finally, most of the import and export of traded goods took place by sea. Considering the high economic and strategic value of the main harbors, we expect state expansion to be concentrated along the coast. To control for these logistical arguments, we include four time-invariant additional indicators in our main models: the length of roads and caravan routes per grid cell, ${ }^{90}$ as well as each grid cell's distance to the nearest coast and nearest international border.

Note that some of these control variables are measured during our study period and can be considered post-treatment with respect to our two main variables of interest. This might generate post-treatment bias. In our robustness checks we address this concern in more detail, but none of our findings are affected by the inclusion or exclusion of any of the post-treatment controls. Details on historical sources for our variables are provided in Appendix Section 1, while summary statistics for all variables are presented in Section 2.

\section{ESTIMATION AND RESULTS}

We start by estimating the effects of our main independent variables on the probability of a station being present in grid cell $i$ in year $t$. Our dependent variables are a simple binary indicator of station presence or the ordinal measure of station type. We begin by estimating pooled logit models that leverage cross-sectional and temporal variation:

$$
\eta_{i t}=\alpha_{t}+\boldsymbol{x}_{i t}^{\prime} \beta+y * \text { resist }_{i t-1}+\theta * \text { controlval }_{i t-1},
$$

where $\eta_{i t}$ is the linear predictor linked to the binary and ordinal outcome indicator via the logit link function. The parameter $\alpha_{t}$ represents year fixed effects to model the overall temporal dynamics of German colonial state expansion, while the vector $\boldsymbol{x}_{i t}^{\prime}$ represents time-varying and time-invariant grid-cell control variables. The two parameters $y, \theta$ represent the effects of violent resistance and the grid cell's territorial control value for state expansion. We cluster standard errors at the grid-cell level to account for heteroskedasticity and arbitrary serial correlation. Table 1 shows the estimated coefficients and associated standard errors.

We start with a brief review of findings for the main control variables. We find clear evidence across the models that road length per grid cell is statistically significant and positively associated with the presence of a station. We also find that the integration of local ethnic groups into the German colonial military is associated with lower degrees of state penetration. Higher population density is associated with a stronger German state presence, which is statistically significant at the 1 per cent level across all models. Distance to the border correlates positively with state presence. Interestingly, the results for variables measuring the potential for economic extraction have no

${ }^{88}$ Acemoglu, Johnson, and Robinson 2001.

${ }^{89}$ Herbst 2000.

${ }^{90}$ Information on caravan routes stems from a map of the Abushiri Revolt in 1892, and information on roads comes from an economic map from 1906. We have geo-referenced both maps and extracted the respective information. The road measure might be partially endogenous to the presence of a station. Excluding this variable from our models does not affect the results with respect to our main variables of interest. 
TABLE 1

Station Presence, Logit

\begin{tabular}{|c|c|c|c|c|c|c|}
\hline & (1) Station Presence & (2) Station Presence & (3) Station Presence & (4) Station Type & (5) Station Type & (6) Station Type \\
\hline Area & $\begin{array}{c}-6.273 \\
(5.369)\end{array}$ & $\begin{array}{c}-6.230 \\
(5.570)\end{array}$ & $\begin{array}{c}-6.161 \\
(5.643)\end{array}$ & $\begin{array}{c}-2.870 \\
(2.307)\end{array}$ & $\begin{array}{c}-3.049 \\
(2.316)\end{array}$ & $\begin{array}{c}-3.606 \\
(2.380)\end{array}$ \\
\hline Caravan Road Length & 0.656 & 0.616 & 0.514 & 0.277 & 0.273 & 0.255 \\
\hline Road Length & $\begin{array}{c}(0.573) \\
1.505^{*} \\
(0.679)\end{array}$ & $\begin{array}{c}(0.568) \\
1.590 * \\
(0.674)\end{array}$ & $\begin{array}{l}(0.564) \\
1.760 * * \\
(0.677)\end{array}$ & $\begin{array}{c}(0.271) \\
0.738 * \\
(0.313)\end{array}$ & $\begin{array}{c}(0.267) \\
0.765 * \\
(0.312)\end{array}$ & $\begin{array}{l}(0.263) \\
0.835^{* *} \\
(0.317)\end{array}$ \\
\hline Disease Environment & $\begin{array}{c}-0.005 \\
(0.041)\end{array}$ & $\begin{array}{c}-0.006 \\
(0.041)\end{array}$ & $\begin{array}{c}-0.013 \\
(0.039)\end{array}$ & $\begin{array}{c}-0.001 \\
(0.019)\end{array}$ & $\begin{array}{c}-0.001 \\
(0.019)\end{array}$ & $\begin{array}{c}0.000 \\
(0.020)\end{array}$ \\
\hline Number of Troops, 1889 & $\begin{array}{c}-0.474^{*} \\
(0.240)\end{array}$ & $\begin{array}{c}-0.466^{*} \\
(0.233)\end{array}$ & $\begin{array}{r}-0.392^{+} \\
(0.216)\end{array}$ & $\begin{array}{r}-0.175^{+} \\
(0.094)\end{array}$ & $\begin{array}{r}-0.177^{+} \\
(0.094)\end{array}$ & $\begin{array}{r}-0.166^{+} \\
(0.096)\end{array}$ \\
\hline Ethnic Population & $\begin{array}{c}-0.005 \\
(0.003)\end{array}$ & $\begin{array}{c}-0.005 \\
(0.003)\end{array}$ & $\begin{array}{r}-0.005^{+} \\
(0.003)\end{array}$ & $\begin{array}{r}-0.003^{+} \\
(0.002)\end{array}$ & $\begin{array}{r}-0.003^{+} \\
(0.002)\end{array}$ & $\begin{array}{r}-0.003^{+} \\
(0.002)\end{array}$ \\
\hline Population Density & $\begin{array}{l}1.474 * * * \\
(0.441)\end{array}$ & $\begin{array}{l}1.434 * * \\
(0.440)\end{array}$ & $\begin{array}{l}1.391^{* *} \\
(0.456)\end{array}$ & $\begin{array}{l}0.680 * * \\
(0.212)\end{array}$ & $\begin{array}{l}0.684^{* *} \\
(0.211)\end{array}$ & $\begin{array}{l}0.703^{* *} \\
(0.216)\end{array}$ \\
\hline Mean Elevation & $\begin{array}{c}-2.815 \\
(2.229)\end{array}$ & $\begin{array}{c}-2.651 \\
(2.176)\end{array}$ & $\begin{array}{c}-2.329 \\
(2.022)\end{array}$ & $\begin{array}{c}-0.864 \\
(0.858)\end{array}$ & $\begin{array}{c}-0.876 \\
(0.861)\end{array}$ & $\begin{array}{c}-1.028 \\
(0.897)\end{array}$ \\
\hline Annual Precipitation & $\begin{array}{l}1.276 \\
(1.045)\end{array}$ & $\begin{array}{l}1.215 \\
(1.054)\end{array}$ & $\begin{array}{l}1.006 \\
(1.088)\end{array}$ & $\begin{array}{c}0.849 \\
(0.522)\end{array}$ & $\begin{array}{c}0.837 \\
(0.521)\end{array}$ & $\begin{array}{c}0.719 \\
(0.535)\end{array}$ \\
\hline Annual Mean Temp & $\begin{array}{c}-0.032 \\
(0.041)\end{array}$ & $\begin{array}{c}-0.028 \\
(0.040)\end{array}$ & $\begin{array}{c}-0.022 \\
(0.035)\end{array}$ & $\begin{array}{c}-0.006 \\
(0.016)\end{array}$ & $\begin{array}{c}-0.006 \\
(0.016)\end{array}$ & $\begin{array}{c}-0.009 \\
(0.016)\end{array}$ \\
\hline Border Distance & $\begin{array}{l}9.528^{* *} \\
(3.183)\end{array}$ & $\begin{array}{l}9.223^{* *} \\
(3.109)\end{array}$ & $\begin{array}{l}8.180^{* *} \\
(3.085)\end{array}$ & $\begin{array}{l}3.539 * * \\
(1.307)\end{array}$ & $\begin{array}{l}3.587 * * \\
(1.306)\end{array}$ & $\begin{array}{l}3.619^{* *} \\
(1.346)\end{array}$ \\
\hline Coastal Distance & $\begin{array}{c}0.263 \\
(1.690)\end{array}$ & $\begin{array}{c}0.391 \\
(1.668)\end{array}$ & $\begin{array}{c}0.688 \\
(1.640)\end{array}$ & $\begin{array}{c}-0.213 \\
(0.645)\end{array}$ & $\begin{array}{c}-0.225 \\
(0.651)\end{array}$ & $\begin{array}{c}-0.098 \\
(0.681)\end{array}$ \\
\hline Soil Quality & $\begin{array}{c}-0.577 \\
(0.603)\end{array}$ & $\begin{array}{c}-0.621 \\
(0.723)\end{array}$ & $\begin{array}{c}-0.753 \\
(0.572)\end{array}$ & $\begin{array}{c}-0.382 \\
(0.321)\end{array}$ & $\begin{array}{c}-0.396 \\
(0.380)\end{array}$ & $\begin{array}{c}-0.377 \\
(0.323)\end{array}$ \\
\hline Cotton price, 1yr lag & $\begin{array}{c}-0.050 \\
(0.057)\end{array}$ & $\begin{array}{c}-0.038 \\
(0.070)\end{array}$ & $\begin{array}{c}-0.012 \\
(0.057)\end{array}$ & $\begin{array}{c}-0.030 \\
(0.023)\end{array}$ & $\begin{array}{c}-0.025 \\
(0.031)\end{array}$ & $\begin{array}{c}-0.009 \\
(0.028)\end{array}$ \\
\hline Soil Quality $\times$ Cotton price, $1 \mathrm{yr}$ lag & $\begin{array}{c}0.015 \\
(0.009)\end{array}$ & $\begin{array}{c}0.016 \\
(0.012)\end{array}$ & $\begin{array}{c}0.018^{*} \\
(0.009)\end{array}$ & $\begin{array}{c}0.008^{*} \\
(0.004)\end{array}$ & $\begin{array}{c}0.008 \\
(0.005)\end{array}$ & $\begin{array}{c}0.009^{*} \\
(0.004)\end{array}$ \\
\hline Rubber Suitability & $\begin{array}{c}-2.074 \\
(1.993)\end{array}$ & $\begin{array}{c}-3.025 \\
(2.078)\end{array}$ & $\begin{array}{r}-3.888^{+} \\
(2.047)\end{array}$ & $\begin{array}{c}-0.688 \\
(0.797)\end{array}$ & $\begin{array}{c}-0.984 \\
(0.808)\end{array}$ & $\begin{array}{r}-1.750^{*} \\
(0.811)\end{array}$ \\
\hline Rubber price, $1 \mathrm{yr}$ lag & $\begin{array}{r}-0.006 \\
(0.015)\end{array}$ & $\begin{array}{c}-0.037 * \\
(0.016)\end{array}$ & $\begin{array}{r}-0.062 * \\
(0.031)\end{array}$ & $\begin{array}{c}-0.001 \\
(0.006)\end{array}$ & $\begin{array}{r}-0.013^{+} \\
(0.007)\end{array}$ & $\begin{array}{r}-0.028^{*} \\
(0.013)\end{array}$ \\
\hline
\end{tabular}


(1) Station Presence

(2) Station Presence

(3) Station Presence

(4) Station Type

(5) Station Type

(6) Station Type

Rubber Suitability $\times$ Rubber price, 1yr lag

0.000

0.010

Battle Index, 1yr lag

$(0.019) \quad(0.020)$

Control Value, 1yr lag

$0.621 * *$

$(0.170)$

$2.292 * *$

$(0.019)$

$-0.004$

$-0.001$

0.006

$(0.007)$

$-0.001$

(0.007)

Battle Index, 2yr lag

Control Value, 2yr lag

(0.590)

(0.062)

$0.499 * * *$

(0.048)

$0.240 * * *$

$0.563 * * *$

(0.143)

$1.888 * *$

(0.489)

$(0.056)$

$0.483^{* * *}$

Battle Index, 5yr lag

Control Value, 5yr lag

Constant

ag

\begin{tabular}{|c|c|c|c|c|c|c|}
\hline Constant & $\begin{array}{c}5.625 \\
(13.266)\end{array}$ & $\begin{array}{c}7.191 \\
(12.695)\end{array}$ & $\begin{array}{c}6.820 \\
(11.601)\end{array}$ & & & \\
\hline Year FE & Yes & Yes & Yes & Yes & Yes & Yes \\
\hline Observations & 7074 & 6681 & 5502 & 7074 & 6681 & 5502 \\
\hline Log-Likelihood & -839.594 & -857.700 & -883.375 & -1447.458 & -1430.959 & -1371.555 \\
\hline AIC & 1751.189 & 1785.400 & 1830.751 & 2972.916 & 2937.918 & 2813.110 \\
\hline
\end{tabular}

Clustered standard errors in parentheses.

Some variables were re-scaled to improve the presentation of results: Number of Troops, 1889 in 100s; Ethnic Population in 10,000s; Mean Elevation in $1 \mathrm{~km}$; Annual Precipitation in 1000s; Border Distance in $1 \mathrm{~km}$; Coastal Distance in $1 \mathrm{~km}$.

${ }^{+} p<0.10, * p<0.05, * * p<0.01, * * * p<0.001$ 


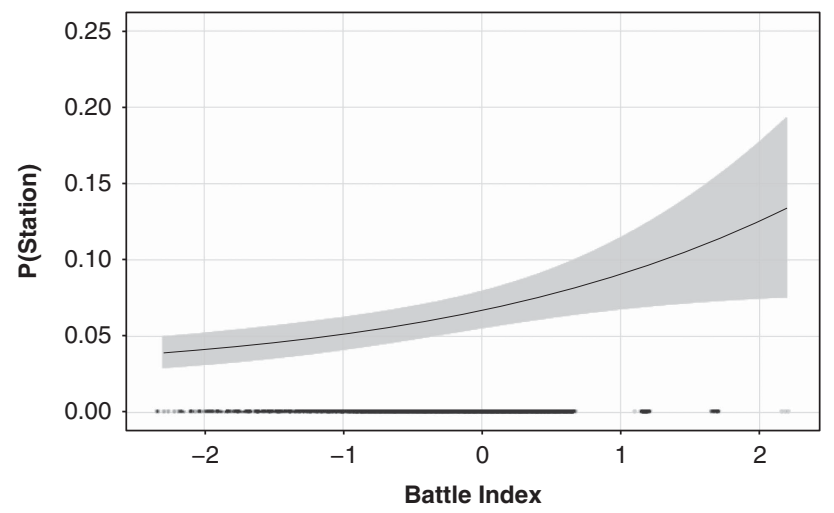

Fig. 2a. Predicted probability of a station in grid cell $\mathrm{i}$ as a function of Battle Index Note: All other variables were set to their means or medians. Simulations were based on estimates from Model 1 in Table 1 .

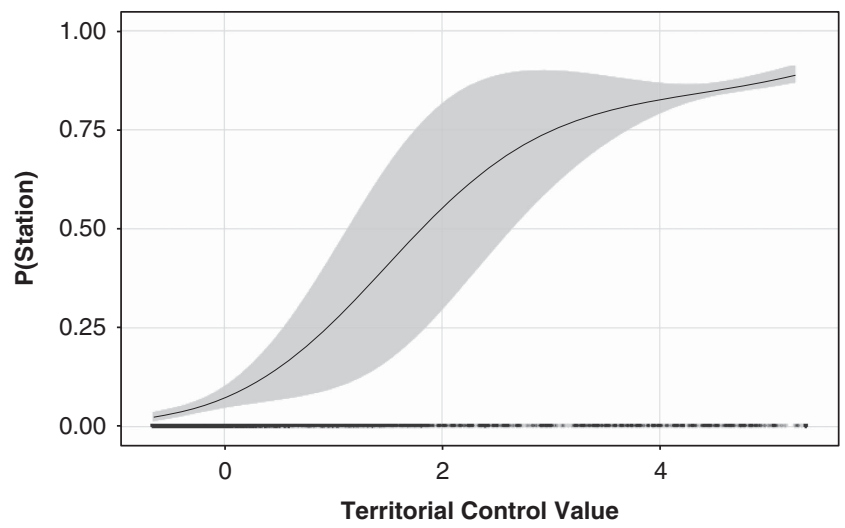

Fig. 2b. Predicted probability of a station in grid cell i as a function of Territorial Control Value.

statistically significant effects. Neither the soil suitability variables nor the interaction term with world market prices attains statistical significance at conventional levels (the constituent term for world market prices is absorbed by the year fixed effects). Most other control variables also fail to consistently attain statistical significance across the three specifications.

The indicator of the territorial control value is positive and highly statistically significant in Models 1-6, indicating that colonial state expansion did adhere to the logic of territorial expansion, extending coverage across the whole territory of the colony. For the territorial control value variable, we can observe a reduction in the size of the coefficient as the lag length increases, which is consistent with the idea that the value of a location diminishes as it becomes integrated into the station network.

Violent resistance against the colonial state, measured via the Battle Index, is estimated to have a positive association with station presence in Models 1-6, reaching statistical significance at the $0.1-5.0$ per cent level. Also note that the size of the coefficient is fairly stable across the different lag lengths. Violent encounters of German troops in preceding years led to the establishment of new stations.

Given the non-linear nature of the model specification, it is difficult to judge the substantive significance of each of the variables with respect to the probability of station presence. We 
тав LE 2 Substantive Effect Comparison: 1 SD Increase at the Median

\begin{tabular}{lcc}
\hline \hline Variable & Estimated Change in P (Station) & $95 \%$ CI \\
\hline Battle Index, 1-yr lag & $+6.9 \%$ & {$[5.6 \%, 8.2 \%]$} \\
Territorial Control Value, 1yr lag & $+4.5 \%$ & {$[3.0 \%, 5.9 \%]$} \\
Road Length & $+5.3 \%$ & {$[3.9 \%, 6.7 \%]$} \\
Number of Troops, 1889 & $-6.9 \%$ & {$[5.6 \%, 8.3 \%]$} \\
Border Distance & $+6.4 \%$ & {$[5.2 \%, 7.6 \%]$} \\
Population Density & $+6.0 \%$ & {$[4.9 \%, 7.1 \%]$} \\
\hline \hline
\end{tabular}

present a series of simple graphs, which display the predicted probability of a station in grid cell $i$ as a function of our two main explanatory variables. ${ }^{91}$

Figure $2 \mathrm{a}$ illustrates the strong effect of violent resistance against the colonial state, as measured by our aggregate Battle Index. A grid cell at the minimum value of the Battle Index variable (that is, with no violent clashes or far from major battles in the preceding year) has an approximate probability of receiving a station of 3.8 per cent. For grid cells at the maximum value, this probability jumps to roughly 13.4 per cent.

Figure $2 \mathrm{~b}$ shows the expected probability of station presence as a function of a grid cell's control value. Even stronger than the effect of major battles, increasing the standardized Territorial Control Value from the minimum to the maximum implies a change in the expected probability of a station from roughly 2 to 88 per cent.

The substantive size of these effects is also more meaningful than other variables in the model. Table 2 displays the marginal effect of a 1-standard-deviation increase in all of the statistically significant variables in the model. Actual violence and strategic importance are as (or even more) important than structural factors like population density or road length.

\section{ROBUSTNESS CHECKS}

To further ascertain the strength of our findings, we conducted a series of robustness checks. Detailed tables and results are available in the Appendix. Here we simply summarize our main findings.

We start by utilizing an alternative way to measure the presence of a station. Considering the vast areas that were to be policed and administered by the small number of stations, state capacity was not primarily a matter of manpower, armament or financial resources, but more a matter of proximity to German stations. Station chiefs emphasized that loyalty toward the German colonial state diminished with increasing distance from the station. Places far away from stations remained 'blind spots' of German colonial power. ${ }^{92}$ To capture this fact, we also create a variable that measures for each grid cell the distance to the nearest German station, instead of the presence of a station in each grid cell. For this dependent variable we estimate a standard ordinary least squares linear regression. When using the distance to the nearest station as a dependent variable, we generate problems of strong spatial autocorrelation, since neighboring cells have very similar values on the dependent variable. To address this concern, we include a temporally lagged spatial lag of our dependent variable. In this analysis we can

\footnotetext{
$91 \mathrm{We}$ are setting all other variables to their respective means and medians. Simulations were implemented using the statistical software R, based on estimates from Model 1 in Table 1.

${ }^{92}$ Pesek 2005.
} 
clearly confirm the findings of Table 1 for our main independent variables (see Appendix Section 3). The Battle Index and Territorial Control Value variables have the expected signs and are statistically significant below the 0.1 per cent level.

In Appendix Section 4 we also present additional results for an alternative ordinal coding of our outcome variable in Models 4-6 from Table 1. This coding treats stations in Rwanda and Burundi slightly differently, due to their special status. These details of the coding scheme have no impact on our substantive results.

In Appendix Section 5 we also provide additional results from alternative grid net definitions. We replicate our main analysis for two alternative, randomly drawn grid-cell configurations as well as grid cells of slightly smaller $(40 \times 40 \mathrm{~km})$ and slightly larger $(60 \times 60 \mathrm{~km})$ size, without affecting our main findings.

Our next robustness check adds the level of pre-colonial political centralization as a control variable (see Appendix Section 6 for detailed results). This is important because it captures one main explanation for the occurrence of indirect rule. ${ }^{93}$ We draw on work by Murdock, Gennaioli and Rainer, and Nunn. Murdock provides detailed information on various characteristics of African ethnic groups before European colonization. ${ }^{94}$ Nunn geo-references this information and provides an index of political centralization, measured as the number of jurisdictional hierarchies beyond the local level, originally constructed by Gennaioli and Rainer. ${ }^{95}$ We match this information to our grid cells. We repeat the estimations in Table 1 to see whether the degree of political organization of ethnic groups interfered with the effects of violent resistance and the territorial strategic value of a grid cell. We find no evidence to that effect. While political centralization has an independent and negative effect on the creation of stations and their respective status, we still find consistent evidence for our two main independent variables. Interestingly, when we interact our measures of the territorial control value and violent resistance with the political centralization variable, we find that this weakens the effects of the five-year lag Battle Index variable in areas with ethnic groups featuring clear political hierarchies. This means that the political centralization of ethnic groups reduced the likelihood of German interference, even if violent resistance occurred in the past. This might indicate that some groups were able to parlay their resistance into a stable bargain with the German colonial administration, but only if they could rely on internal hierarchical structures that facilitated negotiations. Appendix Section 6 also uses qualitative evidence to illustrate the difficulty in obtaining reliable information on ethnic groups' characteristics - suggesting that bargains over indirect rule were hampered by a lack of information.

Parts of the literature have also emphasized the importance of Christian missionaries in shaping colonial legacies. ${ }^{96}$ The presence of missionary stations might confound the relationship between state presence and the effects of violent resistance against (or the territorial expansion of) the colonial state. However, qualitative evidence based on primary sources $^{97}$ suggests that the placement of missionary stations occurred as a result of fierce competition between Protestant and Catholic missionaries inside 'pacified' territories already controlled by the colonial administration. Furthermore, missionary stations were far from homogeneous - displaying considerable variation in terms of location preferences, interaction with the local population and co-operation with the colonial government - which does not

93 Gerring et al. 2011; Mamdani 1996.

94 Gennaioli and Rainer 2007; Murdoch 1967; Nunn 2008.

95 Gennaoili and Rainer 2007; Nunn 2008.

96 Lankina and Getachew 2013; Woodberry 2012.

97 Gensichen 1902; Renner 1971. 
support the argument for a systematic relationship between the location of missionary stations and administrative stations. We explore this issue further by including a control variable in our models that counts the number of missionary stations in each grid cell. This information comes from a report by German mission inspector Martin Schlunk from 1914, which contains the name and location of every missionary station in the colony. It allowed us to geo-code 140 of the 162 active missionary stations in German East Africa in the period under review. Appendix Section 7 provides detailed regression results. When controlling for the number of missionary stations in each grid cell, we still find positive and statistically significant effects for our two main variables of interest.

Appendix Section 8 includes results for models that exclude all post-treatment variables. Specifically, our controls for colonial roads, the number of ethnic troops, ethnic population size and population density are potential pre-treatment covariates. The inclusion or exclusion of these post-treatment controls does not affect any of our substantive results.

We also disaggregate the Battle Index into its constituent measures (the count of major battles and the distance to the nearest battle) and re-estimate the models in Table 1. Again, this difference in measurement has no substantive impact on our findings (see Appendix Section 9).

By pooling our observations across time periods, we might bias our findings due to the influence of unobserved confounders. We address this concern by estimating a series of fixedeffects models (see Appendix Section 10). We begin by dividing the colony into six general regions along roughly equally sized east-west corridors. We then re-estimate our main models, controlling for region fixed effects. This is meant to remove unobserved, time-invariant factors shared within the six regions. Again, this does not affect our main findings. We also add ethnic group settlement area fixed effects, assigning a unique dummy to each ethnic group, or unique combinations of several ethnic groups living in the same grid cell, based on the GIS shapefile supplied by Nunn. ${ }^{98}$ This removes the effect of any unobserved characteristics of local ethnic populations on violent resistance, the strategic value of the territory or our outcome measures. While including this large number of fixed effects weakens the statistical significance of our findings with regard to the Battle Index - there simply is not enough temporal variation in violence to recover a precise estimate - our overall findings are robust. Including a full set of grid-cell fixed effects similarly diminishes the statistical significance of the Battle Index variable, but the coefficient retains its positive sign. The Territorial Control Value variable remains statistically significant in the one- and two-year lag models. Last, we explore this issue further by decomposing the variables into 'between' and 'within' components and estimate a correlated random-effects model. ${ }^{99}$ This reveals that both types of variation have a statistically significant and positive effect on station presence for the Territorial Control Value, while Battle Index has a significant effect for its cross-sectional component. This is likely the case because the majority of variation in the index comes from cross-sectional differences. Section 11 provides additional results for our ordered station-type models that include a lagged dependent variable to account for persistence in the outcome.

Next, we explore the possible endogeneity of the violent resistance measure. While we present qualitative evidence to establish the causal mechanism more firmly below, we also explore an instrumental variables strategy to assuage fears of reverse causality (see Appendix Section 12 for details). We employ information from a German military handbook to construct plausible exogenous instruments for our Battle Index variable. The German military command collected information on local ethnic groups' military capabilities, specifically the estimated size

98 Nunn 2008.

99 Bell and Jones 2015. 
of their armed population, whether there existed a documented history of prior inter-ethnic violence and the degree of local village fortification. ${ }^{100}$ We use the size of the armed population and two dummy variables that indicate whether there was a prior history of violence and fortified villages as instruments for the Battle Index variable. We argue that the main effect of all three factors on station presence operates only via actual violent resistance against German rule and not any other channel - conditional on covariates. We estimate a linear probability two-stage least squares model, controlling for the same set of confounding variables as before. The first stage of the regression shows that the three instruments together are fairly strong - that is, we can reject the null hypothesis of under-identification - and the Kleibergen Wald statistic is larger than the critical value for 20 per cent relative bias. Moreover, the Hansen J statistic indicates that we fail to reject the null hypothesis of exogeneity. The second stage of the model shows that the instrumented Battle Index still has a positive and statistically significant effect on the probability of station presence.

Finally, we further explore why extractive potential had so little effect on the state-building strategy of the German colonial administration. We argue that extraction was a secondary concern that generally followed the primary imperative of territorial control. Taxation by German authorities only commenced after the creation of a colonial station, and was generally constrained to an area within a two-day march from the station. Tax collection efforts were also often interrupted by violent resistance against the state, hence establishing firm territorial control was a necessary pre-condition for fiscal extraction. ${ }^{101}$ Economic extraction also followed the presence of German state power, in part because plantation owners were dependent on forced labor. To illustrate this we rely on a 1906 map that indicates the location of major cotton plantations in German East Africa. We estimate the effect of colonial station presence on the number of plantations in each grid cell, controlling for our standard set of covariates (see Appendix Section 13 for details). We find that cotton production was clearly influenced by the presence of the German colonial state. Station presence, a hot climate and the presence of road infrastructure are the only statistically significant predictors of cotton plantations. This makes sense, since cotton production can take place in a variety of localities, but becomes economically most viable when local labor can be coerced and transportation routes are readily available. ${ }^{102}$

Finally, we use additional qualitative and descriptive quantitative information to assess the plausibility of our arguments (see Appendix Sections 15, 16 and 17). Most notably, we exploit information collected by Nigmann that documents the specific rationale for the creation of thirty-five of the eighty-one stations in our study period. ${ }^{103}$ This information indicates the prime reason as the pacification of specific territories and people. In addition, we illustrate how the strategic concerns of the colonial government superseded costs concerns, for example, related to health risks, when it came to the placement of colonial stations. Moreover, we explore in more detail the German reaction to the Maji Maji uprising, a large-scale revolt against German

\footnotetext{
100 Note that the accuracy of these reports is somewhat unclear. In particular, since we discuss in Appendix Section 6 the difficulty for German administrators of acquiring reliable information, these results have to be regarded with caution.

101 When we construct a panel of station-years and regress total tax revenues on violent resistance and our standard control variables, we find that revenues drop in response to violence, but recover in later years.

${ }^{102}$ In contrast, rubber plantations are not affected by colonial station presence, but are largely affected by the suitability of the soil for rubber production. This indicates that there was much less choice in decisions about where to locate rubber production; this industry remained largely unaffected by the political imperatives governing German colonial state-building efforts.

103 Nigmann 1911.
} 
rule, similarly indicating that the state did establish new stations as a direct reaction to previous instances of violent resistance and to minimize state absence.

\section{CONCLUSION}

Classic state-building theories, especially in the colonial context, emphasize the fundamental role of structural factors - such as extractive activities, prior indigenous political centralization and the local disease environment - in shaping observable patterns of state expansion and consolidation. However, we argue and show that the driving rationale of the German colonial administration in East Africa was the establishment of political stability and territorial control. In effect, this led to a prioritization of state building in both areas with previous violent resistance against colonial rule and areas that promised maximum territorial coverage. Mirroring arguments on the role of outside threats, military competition and state capacity at the national level, we provide evidence for the argument that actual and expected violence may also shape geographical patterns of state building at the sub-national level. ${ }^{104}$

To be sure, colonial state building differs from other forms of state building in, among other things, its scope, the actors involved and its lack of legitimacy. For example, while classic theories view state building as the by-product of a long and arduous process, colonial empires actively attempted to transplant their established understanding of statehood to foreign territories, initially through a strategic process of deepening state penetration and military force.

Nevertheless, our findings help inform the general debate on state building and refine the existing research on colonial state building. In particular, our results cast light on state-building processes occurring under similar conditions in the 'primitive accumulation of power' phase, when the state's authority over its territory exists on paper, but is not reflected in the reach of state infrastructure. As mentioned above, these conditions were at some point in time present in the majority of colonial state-building attempts in sub-Saharan Africa in the late nineteenth and early twentieth centuries, and mirror the challenges other states have faced throughout history. Further analysis in other state-building contexts, other world regions, and other periods of time will be needed to further scrutinize our findings and their transferability.

By highlighting the root causes of historical policy decisions, we also provide a promising avenue for further research on the long-term repercussions of the early phases of state building. In particular, the establishment of de jure authority over a clearly defined territory without external challengers, corroborated by a lack of classic advantages of statehood provided to the domestic population and limited state capacity, resembles Jackson's characterization of many post-colonial states as 'quasi-states' in the period following independence. ${ }^{105}$

\section{REFERENCES}

Acemoglu, Daron, and James Robinson. 2012. Why Nations Fail: The Origins of Power, Prosperity, and Poverty. New York: Crown Publishing Group.

Acemoglu, Daron, Simon Johnson, and James A. Robinson. 2001. The Colonial Origins of Comparative Development: An Empirical Investigation. American Economic Review 91 (5):1369-401.

Bald, Detlef. 1970. Deutsch-Ostafrika 1900-1914. Munich: Weltforum Verlag.

104 Thies 2007; Tilly 1990.

105 Jackson 1989. 
Banerjee, Abhijit, and Lakshmi Iyer. 2005. History, Institutions, and Economic Performance: The Legacy of Colonial Land Tenure Systems in India. American Economic Review 95 (4):1190-213.

Becker, Felicitas. 2004. Traders, Big Men and Prophets: Political Continuity and Crisis in the Maji Maji Rebellion in Southeast Tanzania. Journal of African History 45 (1):1-22.

Berman, Bruce J. 1998. Ethnicity, Patronage and the African State: The Politics of Uncivil Nationalism. African Affairs 97 (388):305-41.

Blattman, Christopher, Jason Hwang and Jeffrey G. Williamson. 2007. Winners and Losers in the Commodity Lottery: The Impact of Terms of Trade Growth and Volatility in the Periphery 1870-1939. Journal of Development Economics 82 (1):156-79.

Boone, Catherine. 2003. Political Topographies of the African State: Territorial Authority and Institutional Choice. New York: Cambridge University Press.

Bruhn, Miriam, and Francisco A. Gallego. 2011. Good, Bad, and Ugly Colonial Activities: Do They Matter for Economic Development. Review of Economics and Statistics 94 (2):433-61.

Bückendorf, Jutta. 1997. 'Schwarz-weiss-rot über Ostafrika!': deutsche Kolonialpläne und afrikanische Realität ['Black-white-red over East-Africa': German Colonial Plans and African Reality']. Münster: LIT Verlag.

Callahan, Mary P. 2002. State Formation in the Shadow of the Raj: Violence, Warfare and Politics in Colonial Burma. Southeast Asian Studies 39 (4):513-36.

Cameron, Donald 1937. Native Administration in Tanganyika and Nigeria. African Affairs XXXVI (Supplement CXLV):3-29.

Cohen, Youssef, Brian R. Brown, and Abramo F. K. Organski. 1981. The Paradoxical Nature of State Making: The Violent Creation of Order. The American Political Science Review 75 (4): 901-10.

Ehrhardt, Karl. 1903. Die geographische Verbreitung der für die Industrie wichtigen Kautschuk- und Guttaperchapflanzen [The Geographic Spread of Rubber and Gutta-percha Trees, which are Important to the German Industry]. Halle: Gebauer-Schwetschke druckerei und verlag m. b. h.

Engerman, Stanley L., and Kenneth L. Sokoloff. 2002. Factor Endowments, Inequality, and Paths of Development Among New World Economies. Economía 3 (1):41-88.

Evans, Peter B., Dietrich Rueschemeyer, and Theda Skocpol. 1985. Bringing the State Back, In. Cambridge and New York: Cambridge University Press.

Finer, Samuel E. 1975. State- and Nation-Building in Europe: The Role of the Military. In The Formation of National States in Western Europe, edited by Charles Tilly, 78-163. Princeton, NJ: Princeton University Press.

Fischer, G., F. Nachtergaele, S. Prieler, H. van Velthuizen, D. Verelst, and D. Wiberg. 2008. Global AgroEcological Zones Assessment for Agriculture (GAEZ 2008). Rome: FAO.

Fukuyama, Francis. 2004. The Imperative of State Building. Journal of Democracy 15 (2):17-31.

Gennaioli, Nicola, and Ilia Rainer. 2007. The Modern Impact of Precolonial Centralization in Africa. Journal of Economic Growth 12 (3):185-234.

Gensichen, Martin. 1902. Die Jüngsten Afrikanischen Missionsgebiete Der Missionsgesellschaft Berlin I, Maschonaland Und Deutsch-Ostafrika in Vergleichung Miteinander [A Comparison of Missionary Society Berlin I.'s New African Mission Territories in Maschonaland and German East-Africa]. Berlin: Buchhandlung der Berliner Evangelischen Missionsgesellschaften.

Gerring, John, Daniel Ziblatt, Johan Van Gorp, and Julián Arévalo. 2011. An Institutional Theory of Direct and Indirect Rule. World Politics 63 (3):377-433.

Gwassa, Gilbert Clement Kamana. 1973. The Outbreak and Development of the Maji Maji War 1905-1907, edited by Wolfgang Apelt, 1st edition. Köln: Rüdiger Köppe.

Hafeneder, Rudolf. 2008. Deutsche Kolonialkartographie 1884-1919 [German Colonial Cartography 1884-1919]. Euskirchen: Universität der Bundeswehr München.

Hariri, Jacob Gerner. 2012. The Autocratic Legacy of Early Statehood. American Political Science Review 106 (3):471-94.

Hartleb, Erich. 1941. Der koloniale Verwaltungsaufbau in Deutsch-Ost-Afrika vor und nach dem Weltkriege: deutsche und englische Verwaltung [Structure of the Colonial Administration in 
German East-Africa before and after the World War: German and English Administration]. Köln: Universität Köln.

Henley, David. 2004. Conflict, Justice, and the Stranger-King Indigenous Roots of Colonial Rule in Indonesia and Elsewhere. Modern Asian Studies 38 (1):85-144.

Herbst, Jeffrey. 2000. States and Power in Africa: Comparative Lessons in Authority and Control. Princeton, NJ: Princeton University Press.

Huillery, Elise. 2011. The Impact of European Settlement Within French West Africa: Did Pre-Colonial Prosperous Areas Fall Behind? Journal of African Economies 20 (2):263-311.

Iliffe, John. 1979. A Modern History of Tanganyika. New York: Cambridge University Press.

Jackson, Robert. 1989. Quasi-States: Sovereignty, International Relations, and the Third World. New York: Cambridge University Press.

Kabwegyere, Tarsis B. 1972. The Dynamics of Colonial Violence: The Inductive System in Uganda. Journal of Peace Research 9 (4):303-14.

Killingray, David. 1986. The Maintenance of Law and Order in British Colonial Africa. African Affairs 85 (340):411-37.

- 1999. Guardians of Empire. Pp. 1-25 in Guardians of Empire: The Armed Forces of the Colonial Powers, C. 1700-1964, edited by David Killingray. Manchester, UK: Manchester University Press.

Klein-Arendt, Reinhard. 2005. Ein Land wird gewaltsam in Besitz genommen. Die Kolonie DeutschOstafrika [A Country is Conquered Violently. The Colony German East-Africa. In Der Maji-MajiKrieg in Deutsch-Ostafrika, 1905-1907 [The Maji-Maji War in German East-Africa 1905-1907], edited by Felicitas Becker and Jigal Beez, 28-58. Berlin: Ch. Links Verlag.

Koponen, Juhani. 1995. Development for Exploitation: German Colonial Policies in Mainland Tanzania, 1884-1914. Helsinki/Hamburg: LIT Verlag.

Lange, Matthew, James Mahoney, and Matthias vom Hau. 2006. Colonialism and Development: A Comparative Analysis of Spanish and British Colonies. American Journal of Sociology 111 (5):1412-62.

Lankina, Tomila, and Lullit Getachew. 2012. Mission or Empire, Word or Sword? The Human Capital Legacy in Postcolonial Democratic Development. American Journal of Political Science 56 (2): 465-83.

Le Meur, Pierre-Yves. 2006. State Making and the Politics of the Frontier in Central Benin. Development and Change 37 (4):871-900.

Levi, Margaret. 1981. The Predatory Theory of Rule. Politics \& Society 10 (4):431-65.

- 1989. Of Rule and Revenue. Berkeley: University of California Press.

Liebenow, J. Gus. 1971. Colonial Rule and Political Development in Tanzania: The Case of the Makonde. Evanston, IL: Northwestern University Press.

Mahoney, James. 2010. Colonialism and Postcolonial Development: Spanish America in Comparative Perspective. New York: Cambridge University Press.

Mamdani, Mahmood. 1996. Citizen and Subject: Contemporary Africa and the Legacy of Late Colonialism. Princeton, NJ: Princeton University Press.

Mann, Michael. 1984. The Autonomous Power of the State: Its Origins, Mechanisms and Results. European Journal of Sociology/Archives Européennes de Sociologie 25 (2):185-213.

Marner, Josef. 1940. Die Klimatischen Bedingungen Für Die Siedlung von Nordeuropäern in Den Tropen [The Climatic Conditions for Northern European Settlements in Tropic Regions]. Hamburg: Hammerich \& Lesser.

Migdal, Joel S. 1988. Strong Societies and Weak States: State-Society Relations and State Capabilities in the Third World. Princeton, NJ: Princeton University Press.

Murdock, George P. 1967. Ethnographic Atlas: A Summary. Pittsburgh, PA: The University of Pittsburgh Press.

Mworoha, Emile. 1987. Histoire du Burundi: des origines a la fin du xixe siecle [The History of Burundi: Origins at the End of the $19^{\text {th }}$ Century]. Paris: Hatier.

Naritomi, Joana, Rodrigo R. Soares, and Juliano J. Assunção. 2012. Institutional Development and Colonial Heritage Within Brazil. The Journal of Economic History 72 (2):393-422. 
Neep, Dr Daniel. 2012. Occupying Syria Under the French Mandate: Insurgency, Space and State Formation, 1st Edition. Cambridge: Cambridge University Press.

Nigmann, Ernst. 1911. Geschichte der kaiserlichen Schutztruppe für Deutsch-Ostafrika [History of the Colonial Protection Force in German East-Africa]. Hamburg: E. S. Mittler und Sohn.

North, Douglass Cecil. 1981. Structure and Change in Economic History. New York: W. W. Norton \& Company Incorporated.

Nunn, Nathan. 2008. The Long-Term Effects of Africa's Slave Trades. Quarterly Journal of Economics 123 (1):139-76.

Organski, Abramo F. K., and Jacek Kugler. 1980. The War Ledger. Chicago, IL: University of Chicago Press.

Pesek, Michael. 2005. Koloniale Herrschaft in Deutsch-Ostafrika: Expeditionen, Militär und Verwaltung seit 1880 [Colonial Rule in German East-Africa: Expeditions, Military, and Administration since 1880]. Frankfurt a.M.: Campus Verlag GmbH.

Renner, Frumentius. 1971. Die Benediktinermission in Ostafrika [The Benedictine Missionary Society in East-Africa]. Regensburg: Eos Verlag.

Schnee, Heinrich. 1920. Deutsches Kolonial-lexikon [German Colonial Lexicon]. Leipzig: Quelle \& Meyer.

Scott, James C. 2009. The Art of Not Being Governed: An Anarchist History of Upland Southeast Asia. New Haven, CT: Yale University Press.

Seidman, Ann Willcox. 1986. Money, Banking, and Public Finance in Africa. London: Zed Books.

Sethuraj, Madhavan R., and Ninan T. Mathew. 1992. Natural Rubber: Biology, Cultivation and Technology. Amsterdam: Elsevier.

Shenton, Robert W. 1986. The Development of Capitalism in Northern Nigeria. Suffolk: James Currey.

Soifer, Hillel, and Matthias vom Hau. 2008. Unpacking the Strength of the State: The Utility of State Infrastructural Power. Studies in Comparative International Development 43 (3-4):219-30.

Soifer, Hillel David. 2006. Authority Over Distance: Explaining Variation in State Infrastructural Power in Latin America. Cambridge, MA: Harvard University.

Steinmetz, George. 2008. The Colonial State as a Social Field: Ethnographic Capital and Native Policy in the German Overseas Empire Before 1914. American Sociological Review 73 (4):589-612.

Thies, Cameron G. 2007. The Political Economy of State Building in Sub-Saharan Africa. The Journal of Politics 69 (3):716-31.

Tibebu, Teshale. 1995. The Making of Modern Ethiopia: 1896-1974. Trenton, NJ: The Red Sea Press. Tilly, Charles. 1990. Coercion, Capital, and European States: AD 990-1990. Oxford: Basil Blackwell.

Trotha, Trutz von. 1994. Koloniale Herrschaft: zur soziologischen Theorie der Staatsentstehung am Beispiel des Schutzgebietes Togo [Colonial Rule: On the Sociological Theory of State Building at the Example of the Protectorate Togo. Tübingen: Mohr Siebeck.

Tsai, Ming-Chang. 1999. State Power, State Embeddedness, and National Development in Less Developed Countries: A Cross-National Analysis. Studies in Comparative International Development 33 (4):66-88.

Weber, Eugen. 1976. Peasants into Frenchmen: The Modernization of Rural France, 1870-1914. Stanford, CA: Stanford University Press.

Whelpton, John. 2005. A History of Nepal. New York: Cambridge University Press.

Wickham-Crowley, Timothy P. 1993. Guerrillas and Revolution in Latin America, Revised edition. Princeton, NJ: Princeton University Press.

Wilson, Nicholas Hoover. 2011. From Reflection to Refraction: State Administration in British India, Circa 1770-1855. American Journal of Sociology 116 (5):1437-77.

Wimmelbrücker, Ludger. 2005. Verbrannte Erde. Zu den Bevölkerungsverlusten als Folge des Maji-MajiKrieges [Scored Earth: On the Casualties as a Result of the Maji-Maji War]. In Der Maji-Maji-Krieg in Deutsch-Ostafrika, 1905-1907 [The Maji-Maji War in German East-Africa, 1905-1907], edited by Felicitas Becker and Jigal Beez, 87-99. Berlin: Ch. Links Verlag.

Young, Crawford. 1994. The African Colonial State in Comparative Perspective. New Haven, CT: Yale University Press.

Young, Robert. 2001. Postcolonialism: An Historical Introduction. Hoboken, NJ: Wiley-Blackwell. 